\title{
Do Family Structure Differences Explain Trends in Wealth Differentials?
}

Robert I. Lerman

\begin{abstract}
Race and ethnic wealth differentials are wide and increasing. Some of the gaps are associated with education differences, but education alone cannot account for the substantially higher net worth of White families than of Black and Hispanic families. As of 2013, the median wealth of Black college graduate families had fallen to only 13 percent of the median wealth of White families. One possible explanation is the significantly lower shares of married couple and married parent households among minorities. For example, even among college graduates, only 41 percent of Black family heads were married, compared with 68 percent of White family heads. Did these trends in family status contribute significantly to differences between Whites, Blacks, and Hispanics in the declines in wealth among college graduates? The author finds that family status changes between 2007 and 2013 were too small to play a large role and even married couple families among Blacks and Hispanics suffered sharp declines in home equity and net worth. Still, married couples retained at least a 70 percent advantage
\end{abstract} over the unmarried groups. (JEL D31, I24, J12, J15)

Federal Reserve Bank of St. Louis Review, First Quarter 2017, 99(1), pp. 85-101. http://dx.doi.org/10.20955/r.2017.85-101

\section{INTRODUCTION}

Today's racial gaps in income and wealth remain major social concerns for the United States. In 2014, the median family incomes of Black and Hispanic families stood at about 55 percent of White median family incomes. Moreover, the wealth differential between White and minority families remains even larger. Some of the income and wealth differentials are associated with the lower educational levels of minority families. For 25- to 59-year-olds as of 2015, the percent of Black men and women with bachelor's or higher degrees stood at 12.6 and 19.6 percent, well below the 37.0 percent rate for White men and the 41.6 percent rate for White women. Yet, even among college graduates, the racial differentials in wealth are enormous and have widened over time.

Robert J. Lerman is an institute fellow at the Urban Institute, research associate at IZA-Bonn, and emeritus professor of economics at American University. This article was prepared for presentation at the symposium, "Does College Level the Playing Field? Racial and Ethnic Differences in Family Wealth Among College-Educated Families," sponsored by the Center for Household Financial Stability and the Research Division of the Federal Reserve Bank of St. Louis, May 25-26, 2016.

(c) 2017, Federal Reserve Bank of St. Louis. The views expressed in this article are those of the author(s) and do not necessarily reflect the views of the Federal Reserve System, the Board of Governors, or the regional Federal Reserve Banks. Articles may be reprinted, reproduced, published, distributed, displayed, and transmitted in their entirety if copyright notice, author name(s), and full citation are included. Abstracts, synopses, and other derivative works may be made only with prior written permission of the Federal Reserve Bank of St. Louis. 
The median net worth of Black college graduate families dropped from 36 percent of the White median in 1989 to only 13 percent in 2013. Moreover, as Emmons and Noeth (2015) show, having a college degree did not protect Black and Hispanic families from the strongly negative impact of the Great Recession on family wealth. Between 2007 and 2013, while the median wealth of Black and Hispanic families headed by a college graduate fell by 60 and 72 percent, respectively, the drop in median wealth for White college graduate families was only about 16 percent.

An illustration of the declines in the wealth of Black professionals recently appeared in an article in the Washington Post (Badger, 2016), highlighting the weak recovery of home prices in a high-end Black neighborhood in the Atlanta area. The article quotes an economic development expert, who pointed out that "The people here make good money...They have good jobs. Their homes are built of the same sturdy brick." According to John O'Callaghan, president of the Atlanta Neighborhood Development Partnership (in Badger, 2016), "Values in South Metro Atlanta, particularly in African American neighborhoods, are coming back very, very slowly. And it's going to be a long time before we get these neighborhoods back to where they were."

The housing market is clearly one area where declines in home prices lowered net worth. But are there demographic reasons as well? The differences in family structure by race and ethnicity are one possible explanation for the racial differentials in wealth patterns and wealth trends. Even among college graduates, over two-thirds (68.2 percent) of White family heads between 25 and 59 years of age were married, while only 40.7 percent of Black family heads were married. Studies suggest marriage is associated with increased male earnings, higher family incomes, and enhanced wealth building (Lerman and Wilcox 2014). Married couples are more likely than unmarried couples to take a long-term perspective that is conducive to asset building. The role of marriage in economic well-being is especially important among families with children. As of 2014, among households with no children, the household income of families headed by married couples is about twice the household income level of the unmarried couples; among those with children, the marriage advantage climbs to about 2.5. Black households experience even larger differentials. While the median income of the unmarried, Black childless households was only about 70 percent of the income of unmarried, White childless households, Black married couples with children achieved a household income about 86 percent of comparable White households.

A second possible role for family structure is the impact of the changing gender mix of college graduates. In recent decades, women have become more likely to attain bachelor's degrees than men. The pattern is especially striking among Black and Hispanic men and women. In the 2012-13 academic year, 123,000 bachelor's degrees were awarded to Black women and only 67,000 to Black men. Among Hispanics, women earned 113,000 bachelor's degrees while men earned 74,000. As a result, we expect minorities to experience an increasing share of women who are college graduates heading families and a lesser tendency than Whites to have families with two college graduates. Such trends could lead to a relative weakening of the economic status of minority college graduates, but not necessarily in the current period. It may take decades for gender shifts in college graduates to exert a large effect on race differences in wealth. 


\section{Table 1}

Family Structure of Households Headed by 25- to 59-Year-Olds with a Bachelor's Degree or Higher by Race (1985-2015)

\begin{tabular}{|c|c|c|c|c|}
\hline \multirow[b]{2}{*}{ Ethnicity, race, year } & \multicolumn{4}{|c|}{ Percent of college graduates in each family status } \\
\hline & $\begin{array}{l}\text { Unmarried, } \\
\text { no children }\end{array}$ & $\begin{array}{c}\text { Married, } \\
\text { no children }\end{array}$ & $\begin{array}{l}\text { Unmarried, } \\
\text { children }\end{array}$ & $\begin{array}{l}\text { Married, } \\
\text { children }\end{array}$ \\
\hline \multicolumn{5}{|l|}{ White, Non-Hispanic } \\
\hline 1985 & 24.9 & 20.6 & 3.8 & 50.6 \\
\hline 1995 & 25.1 & 21.9 & 3.8 & 49.2 \\
\hline 2005 & 24.9 & 22.5 & 4.4 & 48.2 \\
\hline 2015 & 26.8 & 20.4 & 5.0 & 47.8 \\
\hline \multicolumn{5}{|l|}{ Black, Non-Hispanic } \\
\hline 1985 & 37.8 & 11.4 & 11.0 & 39.9 \\
\hline 1995 & 35.7 & 14.2 & 12.9 & 37.2 \\
\hline 2005 & 35.1 & 12.5 & 14.4 & 38.0 \\
\hline 2015 & 37.4 & 12.6 & 14.8 & 35.2 \\
\hline \multicolumn{5}{|l|}{ Hispanic } \\
\hline 1985 & 28.7 & 16.1 & 5.0 & 50.2 \\
\hline 1995 & 33.5 & 15.3 & 6.1 & 45.2 \\
\hline 2005 & 33.1 & 15.1 & 7.2 & 44.6 \\
\hline 2015 & 33.9 & 13.7 & 9.7 & 42.6 \\
\hline
\end{tabular}

NOTE: Here is an example for reading this table. The upper-left cell reveals that 24.9 percent of 25 - to 59 -year-olds with a college degree were unmarried with no children in 1985.

SOURCE: Tabulations from the Current Population Surveys.

This article examines the evidence on the role for marriage and the presence of children in limiting the impact of the economic downturn and in explaining the racial and ethnic differences in the wealth declines among college graduates. Although the focus is on net worth as a whole, we take special account of changes in home equity. The first section presents the data on differential family status patterns, especially shifts taking place during the 2004-15 periods. Next, we examine the ups and downs of net worth, adjusting the dollar value of net worth for inflation. The evidence is from both the Federal Reserve's Survey of Consumer Finances (SCF) and the National Longitudinal Survey of Youth: 1979 (NLSY79). Third, we use the March Current Population Surveys (CPS) to capture family and homeownership trends. Fourth, we develop some multivariate estimates of the effects of marriage differentials and marriage trends, independently of a range of other facts. Finally, we draw conclusions about whether changes in family structure can help explain race-ethnicity differences in recent wealth trends of college graduates.

\section{TRENDS IN FAMILY STRUCTURE BY RACE AND HISPANIC STATUS}

Definitions of family structure vary widely. In this article, families are divided into four types based on the marital status of the family head and the presence of children: (i) unmar- 
Table 2

Family Structure of Households Headed by 25- to 59-Year-Olds with Less than a Bachelor's Degree by Race (1985-2015)

\begin{tabular}{lcccc} 
& \multicolumn{2}{c}{ Percent of non-college graduates in each family status } \\
\cline { 2 - 4 } Ethnicity, race, year & $\begin{array}{c}\text { Unmarried, } \\
\text { no children }\end{array}$ & $\begin{array}{c}\text { Married, } \\
\text { no children }\end{array}$ & $\begin{array}{c}\text { Unmarried, } \\
\text { children }\end{array}$ & $\begin{array}{c}\text { Married, } \\
\text { children }\end{array}$ \\
\hline $\begin{array}{l}\text { White, Non-Hispanic } \\
1985\end{array}$ & 19.8 & 18.2 & 12.7 & 49.3 \\
\hline 1995 & 24.0 & 18.5 & 14.0 & 43.6 \\
\hline 2005 & 28.2 & 20.2 & 14.1 & 37.5 \\
\hline 2015 & 32.2 & 19.2 & 15.4 & 33.2 \\
\hline Black, Non-Hispanic & & & & \\
1985 & 24.5 & 8.3 & 36.9 & 30.3 \\
\hline 1995 & 28.3 & 9.0 & 37.2 & 25.5 \\
\hline 2005 & 35.7 & 10.5 & 33.1 & 17.2 \\
\hline 2015 & 41.0 & 8.9 & 32.8 & \\
\hline Hispanic & & & & 52.1 \\
1985 & 16.3 & 9.5 & 22.1 & 49.2 \\
\hline 1995 & 17.9 & 9.4 & 23.6 & 47.6 \\
\hline 2005 & 21.5 & 9.0 & 21.9 & 41.4 \\
\hline 2015 & 23.4 & 9.1 & 26.1 & \\
\hline
\end{tabular}

NOTE: Here is an example for reading this table. The upper-left cell reveals that 19.8 percent of 25 - to 59 -year-olds with less than a college degree were unmarried with no children in 1985.

SOURCE: Tabulations from March Current Population Survey.

ried, no children; (ii) married, no children; (iii) unmarried with children under age 18; and (iv) married with children under age 18. To identify these patterns and trends, the Annual Social and Economic Supplements of the CPS are used because they contain large representative samples of family heads and have identified bachelor's degrees since 1992 (early surveys measured only years of schooling).

The patterns in Table 1 reveal only modest changes over time in the share of college graduates, ages 25-59, across the four family types. Of all Black college graduates heading households, the proportion married with children declined from about 40 percent in 1985 to 35 percent in 2015. However, non-Hispanic Black college graduates lag behind in marriage overall; in 2015, the married share was 47.8 percent among Blacks and 68.2 percent among Whites. Still, racial differences among college grads vary less by race than do differences among non-college graduates. For non-college grads (Table 2), married couple families with children represent a sharply declining share of households. In 1985, 49 percent of White households headed by someone without a college degree were married couples with at least one child under age 18. By 2015, this figure had dropped to 33 percent. For Black families, the comparable decline went from 30 to 17 percent. A comparison of education groups shows much larger 


\section{Table 3}

College Graduate Share of Selected Demographic Groups, 25- to 59-Year-Olds, by Race (1985-2015)

\begin{tabular}{lcccc} 
& \multicolumn{2}{c}{ Percent of college graduates in each family status } \\
\cline { 2 - 5 } Ethnicity, race, year & $\begin{array}{c}\text { Unmarried, } \\
\text { no children }\end{array}$ & $\begin{array}{c}\text { Married, } \\
\text { no children }\end{array}$ & $\begin{array}{c}\text { Unmarried, } \\
\text { children }\end{array}$ & $\begin{array}{c}\text { Married, } \\
\text { children }\end{array}$ \\
\hline White, Non-Hispanic & 30.1 & & & \\
1985 & 31.0 & 24.7 & 14.5 & 23.4 \\
\hline 1995 & 32.4 & 29.7 & 15.2 & 30.0 \\
\hline 2005 & 35.2 & 33.5 & 19.1 & 37.6 \\
\hline 2015 & & 38.7 & 23.4 & 45.9 \\
\hline Black, Non-Hispanic & 14.3 & & & 14.4 \\
1985 & 15.3 & 14.1 & 6.7 & 18.2 \\
\hline 1995 & 17.2 & 19.4 & 12.8 & 26.7 \\
\hline 2005 & 21.1 & 19.8 & 16.9 & 35.1 \\
\hline 2015 & & 27.0 & & 8.4 \\
\hline Hispanic & 11.5 & & 4.0 & 9.1 \\
1985 & 12.2 & 12.8 & 4.4 & 11.9 \\
\hline 1995 & 13.9 & 13.7 & 10.6 & 16.1 \\
\hline 2005 & 17.1 & 18.3 & 7.1 & \\
\hline 2015 & 21.1 & 10.6 & \\
\hline
\end{tabular}

NOTE: Here is an example of how to read this table. The upper-left cell indicates that college graduates made up 30.1 percent of White, non-Hispanic, unmarried people without children in 1985.

SOURCE: Tabulations from March Current Population Survey.

declines in married parent households between 1985 and 2015 among non-college heads of households than among college graduates heading households.

Restricting the groups to parents, one can compare college graduate parents in married versus unmarried households. Except for White college graduates, the share of parents who were unmarried jumped by about 10 to 11 percentage points between 1985 and 2015. For Black parents, the unmarried share jumped to 41 percent among college graduates and 66 percent among those without a bachelor's degree. Among White, non-Hispanic college graduates, the unmarried share of parents rose by about 50 percent but from a small base. Thus, as of 2015, only 15 percent of White college graduate parents were not married.

Another perspective is to examine the proportion of each marital-status/presence-ofchildren group made up of college graduates. As Table 3 reveals, married families with children were far more likely to be headed by a college graduate in 2015 than in 1985. In fact, nonHispanic White and Hispanic college graduates doubled their share of married parent families, accounting for almost half of White married parent families (45.9 percent). Among Black married parent families, the share of family heads with a bachelor's or higher degree reached over 35 percent by 2015, nearly 2.5 times the 14 percent level of 1985 . 
What is notable about the data is that the composition of families headed by college graduates evolved but showed only a modest change during the post-2005 period when wealth declined. These 2005-15 shifts in family structure look too modest to explain the wealth shortfalls experienced by minority college graduates. Still, several questions arise about the relationship between wealth changes and family structure for minorities. Among them are the following:

- How did the reductions in wealth vary by family structure? Did the reductions in wealth for Black and Hispanic college graduates occur mainly among unmarried families, especially unmarried parents, or were the declines spread across all types of families?

- Did the pattern of wealth reductions with respect to housing and other assets differ by family structure?

- What role did family structure play in the increases in wealth up to 2004 ?

- Did the reductions take place within specific families or were they primarily a cohort phenomenon?

- Were the changes in net worth mirrored by changes in income?

The next sections examine these and related questions drawing on data from three sources - for net worth and related variables, the SCF for cross-sectional changes and the NLSY79 for a longitudinal analysis; for some homeownership and income analyses, the CPS.

\section{NET WORTH IN THE SURVEY OF CONSUMER FINANCES}

The strengths of the SCF include its comprehensive look at assets and liabilities and its coverage of the highest-income and highest-wealth families. One limitation of the SCF is the relatively small sample size of the survey. As a result, estimates for several subgroups are subject to high levels of variability. For this reason, we must treat the estimates for detailed subgroups as subject to error. The net worth figures are in real terms, adjusted to the consumer price index. Again, the focus is on families headed by someone in the 25- to 59-year-old age groups.

The estimates in Table 4 illustrate both the declines in median wealth among minorities as well as the relatively wide swings in the data by detailed subgroup. The tabulations reveal the extremely high differentials by race and Hispanic origin for college graduates, even within family types and even among married parents.

Declines in net worth were experienced by all races and ethnic backgrounds. Among Whites, the median levels of net worth fell from the 2004 and/or 2007 levels into the Great Recession. At the same time, families headed by a married couple retained substantial advantages over families whose heads were unmarried. For Blacks, the dramatic reductions hit nearly all family types in ways that are highly variable. As noted above, some of the numbers in the tabulations are subject to errors. According to these figures, unmarried heads of households with no children ended up with more wealth than did married couples with children. Hispanic married couples suffered incredibly high losses from the 2004-07 periods, when net worth ranged from $\$ 347,000$ to $\$ 384,000$, to the 2010 - 13 period when net worth ranged from $\$ 57,000$ 


\section{Table 4}

Trends in Median Net Worth of Families Headed by 25- to 59-Year-Old College Graduates, by Family Structure and Race (1992-2013)

\begin{tabular}{lrrrr} 
Ethnicity, race, year & $\begin{array}{c}\text { Unmarried, } \\
\text { no children }\end{array}$ & $\begin{array}{c}\text { Married, } \\
\text { no children }\end{array}$ & $\begin{array}{c}\text { Unmarried, } \\
\text { children }\end{array}$ & $\begin{array}{c}\text { Married, } \\
\text { children }\end{array}$ \\
\hline $\begin{array}{l}\text { White, Non-Hispanic } \\
1992\end{array}$ & $\$ 50,384$ & $\$ 171,575$ & & \\
\hline 1995 & 95,672 & 198,842 & 67,758 & $\$ 209,595$ \\
\hline 1998 & 81,483 & 285,275 & 94,205 & 191,405 \\
\hline 2001 & 114,184 & 395,409 & 210,903 & 386,211 \\
\hline 2004 & 100,749 & 430,367 & 76,751 & 405,827 \\
\hline 2007 & 166,847 & 376,361 & 229,937 & 417,455 \\
\hline 2010 & 82,521 & 312,078 & 69,553 & 367,538 \\
\hline 2013 & 77,300 & 300,900 & 69,600 & 355,990 \\
\hline
\end{tabular}

Black, Non-Hispanic

\begin{tabular}{rrrrr}
\hline 1992 & 42,146 & 184,898 & 22,795 & 107,121 \\
\hline 1995 & 36,915 & 25,880 & 109,743 & 222,673 \\
\hline 1998 & 46,531 & 72,891 & 40,956 & 152,101 \\
\hline 2001 & 123,232 & 139,989 & 5,319 & 151,873 \\
\hline 2004 & 22,320 & 185,489 & 119,615 & 129,480 \\
\hline 2007 & 14,933 & 78,371 & 39,275 & 272,008 \\
\hline 2010 & 30,136 & 191,726 & 43,725 & 73,400 \\
\hline 2013 & 31,500 & 48,000 & 16,301 & 20,100
\end{tabular}

\section{Hispanic}

\begin{tabular}{rrrrr}
1992 & 49,896 & 3,250 & $(4,874)$ & 152,240 \\
\hline 1995 & 16,181 & - & 95,581 & 103,246 \\
\hline 1998 & 7,362 & 340,369 & - & 164,009 \\
\hline 2001 & 135,327 & 474,005 & 131,322 & 81,012 \\
\hline 2004 & $(7,608)$ & 107,653 & 25,403 & 347,092 \\
\hline 2007 & 24,589 & 655,151 & 23,242 & 383,884 \\
\hline 2010 & 37,970 & 26,905 & 15,648 & 118,101 \\
\hline 2013 & 24,501 & 136,600 & 11,280 & 56,900 \\
\hline
\end{tabular}

SOURCE: Tabulations from Surveys of Consumer Finances.

to $\$ 118,000$. When using other indicators on the wealth distribution, say the 75 th percentile, the levels change but the trends look similar and wide-ranging. Similarly, other age breakdowns yield similar results on the trends in net worth.

When summarizing the CPS and SCF data, based on cross sections of the population, we find no evidence that family structure accounts for the larger declines in wealth among Black and Hispanic college graduate families than among White college graduates. We now turn to other data with substantially larger samples and that capture trends in homeownership, family incomes, and changes within families over time. 
Table 5

Trends in Homeownership Rates Among 25- to 59-Year-Old College Graduates, by Family Structure, Race, and Hispanic Origin (1985-2015)

\begin{tabular}{|c|c|c|c|c|c|}
\hline \multirow[b]{2}{*}{ Ethnicity, race, year } & \multicolumn{5}{|c|}{ Share of households (\%) } \\
\hline & $\begin{array}{l}\text { Unmarried, } \\
\text { no children }\end{array}$ & $\begin{array}{c}\text { Married, no } \\
\text { children }\end{array}$ & $\begin{array}{l}\text { Unmarried, } \\
\text { children }\end{array}$ & $\begin{array}{l}\text { Married, } \\
\text { children }\end{array}$ & Total \\
\hline \multicolumn{6}{|l|}{ White, Non-Hispanic } \\
\hline 1985 & 47.4 & 74.2 & 71.5 & 88.0 & 74.4 \\
\hline 1995 & 53.8 & 79.4 & 72.0 & 89.8 & 77.8 \\
\hline 2005 & 61.0 & 88.3 & 81.1 & 94.3 & 84.1 \\
\hline 2015 & 53.8 & 81.4 & 70.2 & 88.9 & 77.0 \\
\hline \multicolumn{6}{|l|}{ Black, Non-Hispanic } \\
\hline 1985 & 43.3 & 50.6 & 51.9 & 74.1 & 57.3 \\
\hline 1995 & 45.9 & 74.2 & 49.2 & 77.0 & 61.9 \\
\hline 2005 & 53.0 & 86.7 & 59.5 & 82.2 & 69.2 \\
\hline 2015 & 48.4 & 71.3 & 48.1 & 71.8 & 59.5 \\
\hline \multicolumn{6}{|l|}{ Hispanic } \\
\hline 1985 & 34.9 & 65.5 & 45.7 & 71.8 & 58.9 \\
\hline 1995 & 40.5 & 66.6 & 55.9 & 73.3 & 60.2 \\
\hline 2005 & 56.9 & 72.9 & 57.3 & 79.0 & 69.2 \\
\hline 2015 & 45.3 & 63.6 & 53.8 & 73.5 & 60.6 \\
\hline
\end{tabular}

\section{HOMEOWNERSHIP TRENDS BY FAMILY STATUS AND RACE}

The CPSs provide good data on homeownership and family incomes. We track trends for the college and non-college graduate families of different family types by race. Although homeownership does not capture the net asset positions of families, it is easier to measure than the potential ranges of assets and liabilities. Moreover, the data are less likely to be subject to wide swings, even for detailed subgroups, partly because of the variable and partly because the CPS samples for college graduate heads of families by family type, race, and ethnicity are at least three times the size of comparable groups from the SCF.

The trends in homeownership follow a pattern similar to the trends in net worth, with improvements up to the 2005 peak and then a decline between 2005 and 2015 (Table 5).

Although the 2005-15 declines in homeownership rates cover all groups, White and Hispanic married parents experienced somewhat lower reductions than other family types. Still, no family type escaped the falloff in homeownership rates. At the same time, married couple families retained their enormous advantage in homeownership. Among Black parents, married couples ended the period with a homeownership rate of 72 percent, while unmarried Black parents attained a homeownership rate of 48 percent. Among families with no child under age 18, married couples were much more likely to own a home than unmarried heads 


\section{Table 6}

Median Home Equity of College Graduate Homeowners, by Family Structure and Race (1992-2013)

\begin{tabular}{lrrrr} 
Ethnicity, race, year & $\begin{array}{c}\text { Unmarried, } \\
\text { no children }\end{array}$ & $\begin{array}{c}\text { Married, } \\
\text { no children }\end{array}$ & $\begin{array}{c}\text { Unmarried, } \\
\text { children }\end{array}$ & $\begin{array}{c}\text { Married, } \\
\text { children }\end{array}$ \\
\hline $\begin{array}{l}\text { White, Non-Hispanic } \\
1992\end{array}$ & $\$ 89,362$ & $\$ 116,983$ & & \\
\hline 1995 & 77,412 & 94,109 & $\$ 61,741$ & $\$ 86,112$ \\
\hline 1998 & 68,617 & 92,919 & 92,608 & 75,894 \\
\hline 2001 & 99,804 & 137,888 & 114,906 & 100,067 \\
\hline 2004 & 98,651 & 160,308 & 53,025 & 128,695 \\
\hline 2007 & 112,280 & 165,051 & 142,595 & 175,156 \\
\hline 2010 & 58,943 & 121,102 & 70,732 & 133,962 \\
\hline 2013 & 70,000 & 110,000 & 71,200 & 97,000 \\
\hline
\end{tabular}

Black, Non-Hispanic

\begin{tabular}{rrrrr}
\hline 1992 & 64,991 & 84,488 & 40,619 & 37,370 \\
\hline 1995 & 30,358 & 207,950 & 75,894 & 91,073 \\
\hline 1998 & 35,738 & 61,469 & 24,302 & 37,168 \\
\hline 2001 & 56,468 & 23,638 & 34,144 & 64,348 \\
\hline 2004 & 24,663 & 147,977 & 34,528 & 129,480 \\
\hline 2007 & 35,929 & 39,298 & 140,349 & 123,508 \\
\hline 2010 & 64,302 & 114,671 & 28,936 & 38,581 \\
\hline 2013 & 51,000 & 96,000 & 32,000 & 12,000 \\
\hline
\end{tabular}

\section{Hispanic}

\begin{tabular}{rrrrr}
\hline 1995 & 227,682 & 235,272 & 86,519 & 60,715 \\
\hline 1998 & 61,469 & 428,857 & $\mathrm{NA}$ & 38,597 \\
\hline 2001 & 82,733 & 136,574 & 17,072 & 105,057 \\
\hline 2004 & 4,933 & 129,480 & 120,848 & 186,204 \\
\hline 2007 & 111,157 & 168,419 & $\mathrm{NA}$ & 116,771 \\
\hline 2010 & 41,796 & 11,789 & 16,075 & 50,370 \\
\hline 2013 & 100,000 & 97,000 & 36,000 & 44,000 \\
\hline
\end{tabular}

NOTE: NA, data not available.

SOURCE: Tabulations from Surveys of Consumer Finances.

of families. Although changing family patterns had little to do with the decline in homeownership among Black college graduates, the 2015 differences between Whites and Blacks in family structure do explain over one-quarter of the Black-White homeownership gap for college graduates.

In addition to the decline in homeownership, home values in excess of mortgage debt fell for all types of families. Note in Table 6 that the sharp drops extend to White, Black, and Hispanic married couple homeowners with children. College apparently did not shield these homeowners from massive home equity losses, independently of race and family status. One 
Table 7

Median Household Income by Race and Family Structure Among Households Headed by 25- to 59-Year-Old College Graduates (1985-2015)

\begin{tabular}{lcccc} 
Ethnicity, race, year & $\begin{array}{c}\text { Unmarried, } \\
\text { no children }\end{array}$ & $\begin{array}{c}\text { Married, } \\
\text { no children }\end{array}$ & $\begin{array}{c}\text { Unmarried, } \\
\text { children }\end{array}$ & $\begin{array}{c}\text { Married, } \\
\text { children }\end{array}$ \\
\hline $\begin{array}{l}\text { White, Non-Hispanic } \\
1985\end{array}$ & $\$ 51,145$ & $\$ 88,394$ & $\$ 52,110$ & $\$ 89,405$ \\
\hline 1995 & 57,303 & 103,017 & 58,069 & 107,310 \\
\hline 2005 & 61,377 & 118,000 & 69,502 & 124,018 \\
\hline 2015 & 66,000 & 120,020 & 69,516 & 131,096 \\
\hline Black, Non-Hispanic & & & & \\
1985 & 40,735 & 65,504 & 36,767 & 83,114 \\
\hline 1995 & 50,193 & 87,230 & 54,054 & 90,433 \\
\hline 2005 & 49,560 & 118,118 & 54,616 & 96,841 \\
\hline 2015 & 55,332 & 100,002 & 55,721 & 113,000 \\
\hline Hispanic & & & & \\
1985 & 46,637 & 79,572 & 37,390 & 76,146 \\
\hline 1995 & 53,053 & 87,432 & 52,914 & 86,372 \\
\hline 2005 & 59,000 & 99,216 & 49,560 & 93,366 \\
\hline 2015 & 64,020 & 95,000 & 58,000 & 105,522 \\
\hline SOURCE: Tabulations from March Current Population Survey. & & \\
\hline
\end{tabular}

noteworthy pattern from Table 6 is that married homeowners without children maintained a higher level of home equity than did married homeowners with children. The patterns are similar at higher and lower percentiles of home equity.

\section{HOUSEHOLD INCOME CHANGES OVER THE PAST 30 YEARS}

Did declines in income among college graduate households accompany the falloff in wealth and homeownership? Since all groups experienced a large increase in bachelor's degree completion, the declining selectivity of college graduates might have led to modest gains when comparing bachelor's degrees in 2015 (when bachelor's degrees were common) with bachelor's degree in 1985 (when bachelor's degrees were far less common). We use CPS data to examine the question in Table 7. Surprisingly, changes in median household income among 25- to 59-year-old college graduates heading families generally continued solid increases. At the same time, the gains for households headed by married couples generally exceeded those for unmarried heads of families. Further, it is striking that the racial gaps in household income of families headed by college graduates are modest compared with the enormous differences in wealth. As of 2015, the median annual household income of Black college graduates who were married parents was $\$ 113,000$, or about 86 percent of the comparable median for White married parents. 


\section{Table 8}

Family Structure of Households Headed by 36- to 55-Year-Olds with a Bachelor's Degree or Higher by Race (2000-12)

\begin{tabular}{|c|c|c|c|c|}
\hline \multirow[b]{2}{*}{ Ethnicity, race, year } & \multicolumn{4}{|c|}{ Share of households by marital status of head and presence of children (\%) } \\
\hline & $\begin{array}{l}\text { Unmarried, } \\
\text { no children }\end{array}$ & $\begin{array}{c}\text { Married, } \\
\text { no children }\end{array}$ & $\begin{array}{l}\text { Unmarried, } \\
\text { children }\end{array}$ & $\begin{array}{l}\text { Married, } \\
\text { children }\end{array}$ \\
\hline \multicolumn{5}{|l|}{ White, Non-Hispanic } \\
\hline $2000,36-43$ & 18.2 & 13.0 & 4.8 & 64.0 \\
\hline $2002,38-45$ & 17.0 & 12.2 & 5.6 & 65.3 \\
\hline $2004,40-47$ & 18.2 & 10.8 & 5.7 & 65.3 \\
\hline $2006,42-49$ & 18.3 & 11.9 & 5.8 & 64.0 \\
\hline $2008,44-51$ & 17.8 & 14.7 & 7.0 & 60.5 \\
\hline $2010,46-53$ & 17.7 & 16.6 & 6.7 & 59.1 \\
\hline $2012,48-55$ & 18.3 & 22.0 & 7.8 & 51.9 \\
\hline \multicolumn{5}{|l|}{ Black, Non-Hispanic } \\
\hline $2000,36-43$ & 22.0 & 9.7 & 16.7 & 51.6 \\
\hline $2002,38-45$ & 20.6 & 9.5 & 19.4 & 50.6 \\
\hline $2004,40-47$ & 23.6 & 7.7 & 18.0 & 50.8 \\
\hline $2006,42-49$ & 25.9 & 9.9 & 17.0 & 47.2 \\
\hline $2008,44-51$ & 25.7 & 12.3 & 18.7 & 43.3 \\
\hline $2010,46-53$ & 27.1 & 13.1 & 16.8 & 43.0 \\
\hline $2012,48-55$ & 27.5 & 17.8 & 17.3 & 37.4 \\
\hline \multicolumn{5}{|l|}{ Hispanic } \\
\hline $2000,36-43$ & 17.0 & 13.5 & 6.6 & 63.0 \\
\hline $2002,38-45$ & 15.4 & 11.2 & 8.4 & 64.9 \\
\hline $2004,40-47$ & 16.9 & 10.5 & 10.8 & 61.8 \\
\hline $2006,42-49$ & 15.3 & 12.1 & 9.4 & 63.3 \\
\hline $2008,44-51$ & 18.2 & 15.1 & 10.3 & 56.4 \\
\hline $2010,46-53$ & 18.6 & 16.6 & 12.1 & 52.7 \\
\hline $2012,48-55$ & 19.3 & 24.8 & 11.0 & 44.8 \\
\hline
\end{tabular}

\section{WEALTH AND FAMILY CHANGES WITHIN A COHORT}

Following individuals within a cohort over time offers an alternative perspective on how changes in wealth interact with family structure. The NLSY79 provides data on individuals from ages 14-21 through ages 47-54. In addition to an enormous array of control variables, the NLSY79 includes information on net worth and homeownerships during the 2008-12 period. The most recent year of data is 2012, when the economy was still in the early stages of recovery and a year before the last year of SCF data. Still, the NLSY79 reveals how wealth changes took place for individuals. We examine trends based on the same family status categories used in the SCF and CPS analyses: unmarried, no children; married, no children; unmarried, children; and married, children. For the 2004-12 period highlighted in the SCF 
Table 9

Real Median Net Worth of Households Headed by a Cohort of 34- to 41-Year-Olds with a Bachelor's Degree or Higher by Race (2000-12)

\begin{tabular}{lccrc} 
Ethnicity, race, year & $\begin{array}{c}\text { Unmarried, } \\
\text { no children }\end{array}$ & $\begin{array}{c}\text { Married, } \\
\text { no children }\end{array}$ & $\begin{array}{c}\text { Unmarried, } \\
\text { children }\end{array}$ & $\begin{array}{c}\text { Married, } \\
\text { children }\end{array}$ \\
\hline White, Non-Hispanic & & & & \\
1998, 34-41 & $\$ 80,982$ & $\$ 145,369$ & $\$ 61,599$ & $\$ 189,113$ \\
\hline $2000,36-43$ & 98,805 & 213,822 & 73,529 & 265,523 \\
\hline $2004,40-47$ & 154,976 & 286,884 & 131,316 & 382,118 \\
\hline $2008,44-51$ & 174,986 & 397,695 & 173,952 & 495,263 \\
\hline $2012,48-55$ & 204,900 & 442,000 & 199,000 & 507,500 \\
\hline Black, Non-Hispanic & & & & \\
$1998,34-41$ & 13,683 & 67,985 & 33,588 & 64,387 \\
\hline $2000,36-43$ & 34,595 & 151,910 & 12,656 & 88,082 \\
\hline $2004,40-47$ & 47,913 & 127,175 & 54,774 & 150,244 \\
\hline $2008,44-51$ & 24,286 & 222,550 & 30,755 & 200,969 \\
\hline $2012,48-55$ & 18,500 & 145,000 & 21,000 & 172,000 \\
\hline Hispanic & & & & \\
$1998,34-41$ & 32,526 & 178,957 & 1,195 & 142,051 \\
\hline $2000,36-43$ & 38,603 & 158,292 & 65,742 & 182,547 \\
\hline $2004,40-47$ & 111,205 & 211,643 & 106,591 & 328,290 \\
\hline $2008,44-51$ & 85,054 & 358,456 & 127,793 & 466,597 \\
\hline $2012,48-55$ & 50,500 & 336,750 & 81,500 & 288,000 \\
\hline SOURCE: Tabulations from National Longitudinal Survey of Youth, 1979. & & \\
\hline
\end{tabular}

and CPS analyses of 25- to 59 year-olds, the NLSY respondents were 40-47 years old in 2004 and 48-55 years old in 2012. Thus, when using the NLSY, the 2004-12 periods capture not only changes in the economy but also the aging of the survey respondents.

The age-family profiles of college graduates indicate that the number of married parent families peaks among individuals between their late 30 s and mid-40s, with the share of married couples with no children rising throughout the period (Table 8). Although the gap in unmarried parenthood is wide in percentage terms between Whites and Blacks, the patterns differ only modestly between Hispanic and White college graduates in their late 30 s through their mid-50s. The share of unmarried individuals with no children present differs substantially between Blacks versus Hispanics and Whites. The gaps in the overall married shares of the cohorts are especially wide; about 74 percent of White college graduates in their late $40 \mathrm{~s}$ through their mid-50s were married, compared with about 55 percent of Black college graduates and about 70 percent of Hispanic college graduates.

The wealth trends in Table 9 show similarities and differences with those evident in the SCF. In both cases, the differentials by family structure are quite large, especially by marital status. Black married families have about seven to eight times the wealth as unmarried Black families. The percentage gaps are lower for Whites and Hispanics but very substantial in abso- 
lute terms. Among those without children, the wealth differentials by marital status are especially striking, especially among Black and Hispanic graduates in 2008.

Turning to the changes in wealth over the most recent recession, we find that 2012 brings a decline in net worth within population groups for Blacks and Hispanics, but not nearly as severe as the drop-off indicated in the SCF. As of 2012, Black married parents with a bachelor's degree or higher had a median wealth of over \$170,000 in 2012, below the 2004 level but $\$ 29,000$ above the 2008 level. Non-Hispanic White college graduates experienced an increase in net worth between 2008 and 2012 for most population groups. White married parents suffered a decline in net worth of over $\$ 60,000$ between 2007 and 2013 according to the SCF, but an increase of about $\$ 12,000$ in the longitudinal NLSY data.

\section{INCORPORATING FAMILY PATTERNS IN A MULTIVARIATE APPROACH}

Tabulations reveal patterns and trends but do not capture the interactions between variables. This section examines the factors associated with changes in net worth, focusing on year and family structure variables. The evidence comes from two sets of multivariate analysesone from examining different cross sections of individuals in the SCF data and the other from examining the same individuals over time in the NLSY data. In both cases, the analyses are restricted to college graduates.

In interpreting the results described in Tables 10 and 11, the coefficients represent the percentage change in net worth for a unit change in the relevant variable. Thus, in Table 10 for non-Hispanic White families, moving from the base year 2000 to the year 2004 leads to an expected decline of 3.7 percent in net worth, after controlling for age. In the second set of regressions in Table 10, which include family structure variables, the decline associated with 2004 is an expected 1.3 percent, after controlling for age and the family structure variables. The $t$-values are linked to the statistical significance of the estimates. A $t$-value of 1.6 is required for the coefficient to be statistically significant at the 10 percent level and a $t$-value of around 2 is required for statistical significance at the 5 percent level.

Turning to Table 10, we find the sharp and frequently statistically significant declines in net worth associated with several years after 2000. The declines extend to White as well as Black and Hispanic college graduates. For Whites, net worth in 2013 is 19 percent below the 2000 level after accounting for age and age squared, and 16 percent below the 2000 level after accounting for the two age variables and the family structure variables. In all cases, the family status variables exert large percentage effects on net worth and generally lower the impact of various years. Thus, for Blacks, the impact of marriage and having children is (i) to raise net worth by 55.1 percent - the family structure variables lower the negative effect of 2013 from 20.4 percent to 13.4 percent-and (ii) to eliminate the statistical significance of the differential between 2013 and 2000 (the base year). The patterns are similar for White and Hispanic households, with family structure variables affecting net worth and reducing the year effects.

Because the NLSY follows the same individuals over time, we can examine how recent years and changes in family structure affect changes in net worth. The focus is on changes for the same individual and not differences between individuals. One approach is to use fixed 
Table 10

SCF Estimates of Year and Family Structure Effects on the Natural Log of Net Worth of 25to 59-Year-Old College Graduates, by Race and Hispanic Status (2001-13)

\begin{tabular}{|c|c|c|c|c|}
\hline Variables by race & Coefficient & $t$-Value & Coefficient & $t$-Value \\
\hline \multicolumn{5}{|l|}{ White, Non-Hispanic } \\
\hline Age & 0.216 & 22.9 & 0.166 & 17.4 \\
\hline Age squared & -0.002 & -15.3 & -0.001 & -10.2 \\
\hline Married, children & - & - & 1.058 & 44.8 \\
\hline Married, no children & - & - & 0.952 & 35.4 \\
\hline Unmarried, children & - & - & -0.043 & -1.0 \\
\hline Year 2004 & -0.037 & -1.3 & -0.013 & -0.5 \\
\hline Year 2007 & 0.024 & 0.8 & 0.076 & 2.7 \\
\hline Year 2010 & -0.148 & -4.9 & -0.122 & -4.2 \\
\hline Year 2013 & -0.190 & -6.4 & -0.160 & -5.6 \\
\hline Constant & 6.544 & 33.0 & 6.850 & 34.5 \\
\hline \multicolumn{5}{|l|}{ Black, Non-Hispanic } \\
\hline Age & 0.197 & 5.4 & 0.142 & 3.7 \\
\hline Age squared & -0.002 & -3.8 & -0.001 & -2.2 \\
\hline Married, children & - & - & 0.551 & 6.0 \\
\hline Married, no children & - & - & 0.189 & 1.6 \\
\hline Unmarried, children & - & - & -0.143 & -1.4 \\
\hline Year 2004 & -0.262 & -2.3 & -0.176 & -1.5 \\
\hline Year 2007 & 0.057 & 0.5 & 0.042 & 0.4 \\
\hline Year 2010 & -0.316 & -2.7 & -0.217 & -1.9 \\
\hline Year 2013 & -0.204 & -1.7 & -0.134 & -1.1 \\
\hline Constant & 6.206 & 8.1 & 7.082 & 9.0 \\
\hline \multicolumn{5}{|l|}{ Hispanic } \\
\hline Age & 0.222 & 4.0 & 0.209 & 3.8 \\
\hline Age squared & -0.002 & -2.9 & -0.002 & -2.7 \\
\hline Married, children & - & - & 0.415 & 3.2 \\
\hline Married, no children & - & - & 0.558 & 3.8 \\
\hline Unmarried, children & - & - & -0.712 & -4.3 \\
\hline Year 2004 & 0.318 & 1.7 & 0.173 & 0.9 \\
\hline Year 2007 & 0.941 & 5.4 & 0.791 & 4.6 \\
\hline Year 2010 & -0.421 & -2.7 & -0.336 & -2.2 \\
\hline Year 2013 & -0.083 & -0.5 & -0.083 & -0.5 \\
\hline Constant & 5.906 & 5.4 & 6.018 & 5.5 \\
\hline
\end{tabular}




\section{Table 11}

\section{Estimates of Percentage Changes in Wealth Associated with Year and Family Structure of 31- to 54-Year-Old College Graduates (2001-12)}

\begin{tabular}{|c|c|c|c|c|}
\hline Variables by race & Coefficient & $t$-Value & Coefficient & $t$-Value \\
\hline \multicolumn{5}{|l|}{ White, Non-Hispanic } \\
\hline Year 2000 & 0.438 & 14.3 & 0.422 & 14.0 \\
\hline Year 2004 & 0.718 & 23.3 & 0.699 & 22.9 \\
\hline Year 2008 & 0.967 & 31.2 & 0.959 & 31.4 \\
\hline Year 2012 & 0.962 & 30.1 & 0.974 & 30.9 \\
\hline Married, children & - & - & 0.690 & 12.1 \\
\hline Married, no children & - & - & 0.557 & 9.6 \\
\hline Unmarried, children & - & - & 0.094 & 1.2 \\
\hline Constant & 11.870 & 665.1 & 11.361 & 245.6 \\
\hline \multicolumn{5}{|l|}{ Black, Non-Hispanic } \\
\hline Year 2000 & 0.485 & 6.3 & 0.470 & 6.1 \\
\hline Year 2004 & 0.834 & 10.8 & 0.812 & 10.5 \\
\hline Year 2008 & 1.105 & 14.4 & 1.082 & 14.2 \\
\hline Year 2012 & 0.974 & 12.2 & 0.951 & 11.9 \\
\hline Married, children & - & - & 0.392 & 2.9 \\
\hline Married, no children & - & - & 0.485 & 3.4 \\
\hline Unmarried, children & - & - & -0.074 & -0.5 \\
\hline Constant & 10.746 & 238.1 & 10.524 & 110.3 \\
\hline \multicolumn{5}{|l|}{ Hispanic } \\
\hline Year 2000 & 0.444 & 5.1 & 0.420 & 4.9 \\
\hline Year 2004 & 0.973 & 11.0 & 0.976 & 11.0 \\
\hline Year 2008 & 1.266 & 14.4 & 1.277 & 14.6 \\
\hline Year 2012 & 1.108 & 12.2 & 1.125 & 12.4 \\
\hline Married, children & - & - & 0.666 & 4.3 \\
\hline Married, no children & - & - & 0.527 & 3.0 \\
\hline Unmarried, children & - & - & 0.056 & 0.3 \\
\hline Constant & 11.322 & 223.1 & 10.849 & 84.5 \\
\hline
\end{tabular}

SOURCE: Fixed effects regressions based on the National Longitudinal Survey of Youth, 1979.

effects regressions. With this procedure, the effect of independent variables is measured in a way that controls for all of the initial observed and unobserved characteristics of the individual, including his or her ability, schooling, saving propensity, and personality. Thus, the estimates cumulate the changes in net worth for families of particular individuals with respect to changes in the independent variables. The family structure variables show how net worth changes in the context of family structure changes. The age variable captures the change in net worth with each year of age. More recent years reflect, in part, changes in wealth over parts of the life cycle. Instead of capturing how people in different circumstances attain different wealth levels, the fixed effect analyses show how wealth evolves for the same individuals. 
The results in Table 11 indicate that wealth rises over the life cycle and did not decrease substantially between 2008 and 2012 for the cohort of 43- to 50-year-olds in 2008. In fact, real wealth is substantially higher in 2012 for this group than in 2004, 2000, and 1996. We do observe a modest decline between 2008 and 2012 for all groups. For example, wealth for nonHispanic Blacks was 110 percent higher in 2008 than in 1996, but only 97 percent higher in 2012 than in 1998. The 2008-12 declines are high for all three groups. The family structure variables exert powerful effects, indicating that changing one's status with respect to marriage and the presence of children influences one's net worth. The periods in which individuals are married show substantially higher wealth; only a modest gap appears between married parents and other married couples. Those who become unmarried with children have about the same net worth as those unmarried without children (the base category). Further, the family structure changes slightly mitigate the year effects for non-Hispanic Whites and Blacks, but they enhance the year effects among Hispanics.

\section{CONCLUSION}

Net worth declined dramatically for Americans in the wake of the 2008-09 collapse of home prices. College graduates of all race and ethnic categories did not escape the drop in nonliquid wealth. Between 2007 and 2013, White homeowners who were married and college graduates experienced a decline in their median home equity of about $\$ 80,000$; among Black homeowners, the decline in median home equity was an astounding $\$ 110,000$, falling from $\$ 123,000$ to about $\$ 12,000$.

This article examines the potential role of the changing family in explaining why Black and Hispanic families headed by college graduates were unable to withstand the decline in net worth. The main conclusions are that (i) family status changes between 2007 and 2013 were too small to account for much of the wealth decline among Black and Hispanic college graduates, and (ii) even married couple families among Blacks and Hispanics suffered sharp declines in home equity and net worth. One should not interpret these results as indicating a modest role for college graduation and for marriage in maintaining family wealth. In fact, the percentage gains in wealth associated with graduating college and with marriage remained high after the Great Recession. In 2007, Black college graduates had a 140 percent advantage in net worth over nongraduates; by 2013, the advantage had reached 177 percent. Although the wealth differentials between married Black college graduates and unmarried graduates declined, married couples retained at least a 70 percent advantage over the unmarried groups.

A major reason for the losses was the decline in home values, leading to a decline in home equity. While declining home values can have ongoing consequences in the risks of foreclosure and in making refinancing difficult, a fall in one's home value is often not as harmful as other wealth losses. One reason is that when a homeowner experiences a decline, others in the community are likely to experience a similar decline in their home values. As a result, the loss in effective purchasing power of a home is modest for those staying in their community. A second reason is that many homeowners have fixed-rate payments that are independent of the home's value or no mortgage payments at all. For these households, the home is less a 
financial asset than a place to live; the declining home value does not raise the cost of living in their housing unit.

The SCF differentials and trends cited in this article show patterns for 25 to 59 -year-olds in each year. To track a single group as it aged, we followed a cohort of 35- to 42-year-olds in 2000 through the 2012 period using the NLSY79. The estimates of net worth trends from 2004 through 2012 capture both the life cycle patterns of asset accumulation as well as the impacts of the Great Recession. These results reveal the cohort's ability to maintain the vast bulk of their net worth even though some reductions took place between 2008 and 2012. For this cohort, marriage and other favorable family structures did convey a net worth advantage and did mitigate the 2008-12 declines in net worth.

Reducing racial wealth gaps remains a serious challenge, even among Black college graduates. The data reveal that income differences are far more limited than are wealth differences among all types of families and marital status, even among college graduates. Ensuring that Black families have sufficient credit to take advantage of historically low mortgage interest rates and home prices should remain a top priority. Such policies can lower the monthly costs (Lerman, 2011) and the risks of long-term rent increases associated with paying for housing (Sinai and Souleles, 2005). In addition, as home prices return to an upward trend, it is important that minority households are able to participate and regain lost wealth.

\section{REFERENCES}

Badger, Emily. "'This Can't Happen by Accident." Wonkblog, May 2, 2016; Washington Post, May 2, 2016, p. A1; https://www.washingtonpost.com/graphics/business/wonk/housing/atlanta/.

Board of Governors of the Federal Reserve System. Survey of Consumer Finances; https://www.federalreserve.gov/econresdata/scf/scfindex.htm.

Emmons, William R. and Noeth, Bryan J. "Why Didn't Higher Education Protect Hispanic and Black Wealth?" Federal Reserve Bank of St. Louis In the Balance: Perspectives on Household Balance Sheets, August 2015; https://www.stlouisfed.org/ /media/Publications/In\%20the\%20Balance/Images/Issue_12/ITB August_2015.pdf.

Lerman, Robert. "Homeownership Vouchers: A Plan to Reinvigorate the Economy While Helping Low-Income Families." Washington, DC: Progressive Policy Institute, March 2011; http://www.progressivefix.com/wp-content/uploads/2011/03/3.2011 Lerman Homeowner-Vouchers.pdf.

Lerman, Robert I. and Wilcox, W. Bradford. For Richer, For Poorer: How Families Structure Economic Success in America. Washington, DC: American Enterprise Institute, 2014; http://www.aei.org/wp-content/uploads/2014/10/IFS-ForRicherForPoorer-Final Web.pdf.

Sinai, Todd and Souleles, Nicholas S. "Owner-Occupied Housing as a Hedge Against Rent Risk." Quarterly Journal of Economics, May 2005, 120(2), pp. 763-89; https://doi.org/10.1093/qje/120.2.763.

U.S. Census Bureau and U.S. Bureau of Labor Statistics. Current Population Survey; http://www.census.gov/programs-surveys/cps.html.

U.S. Department of Labor, Bureau of Labor Statistics. National Longitudinal Survey of Youth: 1979 (NLSY79); https://www.bls.gov/nls/nlsy79.htm. 
